\title{
PUBLICATIONS FOR SALE
}

by the

\section{AMERICAN BRYOLOGICAL AND LICHENOLOGICAL SOCIETY}

\section{THE BRYOLOGIST}

One of North America's oldest botanical journals - founded in 1898.

Broken sets. Individual numbers.

Immediate delivery. Some numbers reprinted by photo-offset or are no longer available.

All prices strictly net. No discounts.

Volumes $1-4$ (1898-1901) $-\$ 5.00$ per volume; single numbers, $\$ 2.00$. Volumes 5-36 (1902-1933) $-\$ 6.00$ per volume; single numbers, $\$ 2.00$. Volumes 37-49 (1934-1946)-\$10.00 per volume; single numbers, $\$ 3.00$. Volumes $50-69(1947-1966)-\$ 16.00$ per volume; single numbers, $\$ 5.00$ Volumes $70-76$ (1967-1973) $-\$ 25.00$ per volume; single numbers, $\$ 7.00$. Volumes 77-81 (1974-1978) - \$40.00 per volume; single numbers, $\$ 11.00$. Volumes 82-84 (1979-1981) - \$50.00 per volume; single numbers, $\$ 15.00$. Volumes $85-89$ (1982-1986) $-\$ 60.00$ per volume; single numbers, $\$ 18.00$.

The BRyologist: Index to VOLumes 1-60. A cumulative index for the years 1898-1957. 217 pages. 1959 , reprinted $1975 . \$ 8.00$, postpaid.

The Bryologist: Index to Volumes 61-75, 1958-1972. Edited by Norton G. Miller. 193 pages. 1976. \$15.00, postpaid.

Both indexes ordered together: $\$ 21.00$, postpaid.

A Fourth Checklist of the Lichens of the Continental United States and Canada by Mason E. Hale, Jr. \& William Louis Culberson. Reprinted from The Bryologist 73: 499-543. 1970, reprinted $1975 . \$ 3.00$, postpaid.

Supplement to "Chemical and Botanical Guide to Lichen Products" by Chicita F. Culberson. Reprinted from THE BRYOLOGIST 73: 177-377. 1970, reprinted 1976. \$8.00, postpaid.

Second Supplement to "Chemical and Botanical Guide to Lichen Products" by Chicita F. Culberson, William Louis Culberson \& Anita Johnson. 400 pages. 1977. \$12.00, postpaid. Both supplements ordered together: $\$ 18.00$, postpaid.

A New List of Mosses of North America North of Mexico by Howard A. Crum, William C. Steere \& Lewis E. Anderson. Reprinted from The BRyologist 76: 85-130. 1973. \$4.00, postpaid.

The Authorities for the Epithets of Mosses, Hepatics, and Lichens by Geneva Sayre, C. E. B. Bonner \& William Louis Culberson. Reprinted from The Bryologist 67: 113-135. 1964, reprinted 1975. $\$ 2.00$, postpaid.

A Checklist of THE Liverworts AND Hornworts of North AMERICA by Raymond Siotler \& Barbara Crandall-Stotler. Reprinted from THE BRYOLOGIST 80: 405-428. 1977. \$3.00, postpaid.

Authors of Names of Bryophytes and the Present location of Their Herbaria by Geneva Sayre. Reprinted from THE BRYOLOGIST 80: 502-521. 1977. \$3.00, postpaid.

Proceedings of the IAB/ABLS Symposium on the Biological Significance of Morphological Characters in Bryophytes, convened by $M$. R. Crosby and $W$. B. Schofield at the Second International Congress of Systematic and Evolutionary Biology, Vancouver, British Columbia, Canada, 17-24 July 1980. Reprinted from The Bryologist 84: 149-211. 1981. \$6.00, postpaid.

IndEX HePaticarum SUPPlementum: 1974-1975 by John J. Engel. Reprinted from Taxon 27(4): 393-418. 1978. \$2.00 postpaid.

Index HePatiCaRum Supplementum: 1976-1977 by John J. Engel. Reprinted from Taxon 30(2): 518-537. 1981. \$2.00 postpaid

Index Muscorum Supplementum: 1974-1975 by Marshall R. Crosby. Reprinted from Taxon 26(2/ 3): 285-307. 1977. $\$ 2.00$ postpaid.

INdeX Muscorum Supplementum: 1976-1977 by Marshall R. Crosby. Reprinted from Taxon 28(1,2/ 3): 237-264. 1979. $\$ 2.00$ postpaid.

Index Muscorum Supplementum: 1978-1979 by Marshall R. Crosby and Cheryl R. Bauer. Reprinted from Taxon 30(3): 667-693. $\$ 2.00$ postpaid.

Index Muscorum SuPplementum: 1980-1981 by Marshall R. Crosby and Chery/ R. Bauer. Reprinted from Taxon 32(4): 670-691. $\$ 2.00$ postpaid.

Payment must be received before orders will be sent. Send orders to: The Bryologist, Paul L. Redfearn, Jr., Business Manager, Department of Biology, Southwest Missouri State University, Springfield, MO 65804-0095. 


\section{ACADEMIC PRESS BOOKS AND JOURNALS}

Academic Press publishes books and journals in many areas of Science including:

- Acoustics, Agriculture, Anatomy, Anthropology, Archaeology, Audiology

- Biochemistry, Biology, Botany

- Cancer research, Cardiology, Chemistry, Computer science

- Economics, Engineering, Environmental science

- Food Science

- Geography, Geology

- Immunology

- Materials technology, Mathematics, Microbiology

- Neuroscience, Nutrition

- Oncology, Ornithology

- Pathology, Pharmacology, Physics, Physiology, Psychiatry, Psychology

- Religion

- Sociology, Speech, Surgery

- Toxicology

- Virology

- Zoology

Please send me information on books/journals (delete as necessary) in the following areas:

\section{Life Sciences Physical Sciences}

\section{Medicine Social and Behavioural Sciences}

Please send me details of new publications on:

Name

Address

Post Code

Mail to: Academic Press

24-28 Oval Road, London NW1 7DX, U.K.

Orlando, FL 32887, USA. 
Instructions for Authors: Papers and short notes from contributors anywhere in the world are welcome for consideration for publication in The Lichenologist and may be on any aspect of lichenology. However, priority in publication will be given to those who are members of the British Lichen Society.

Manuscripts must be typewritten on foolscap or A4 size paper in double or treble spacing with 1 inch margins all round and submitted in duplicate to the Senior Editor.

Line illustrations must be in black ink on stiff white card, preferably Bristol board.

As a guide to the layout of synonymy, keys, references, etc., recent issues should be consulted. The spellings of locality names in Britain and abroad must follow those of the most recent editions of maps published by the Ordnance Survey and The Times Atlas of the World, respectively. Titles of periodicals should be abbreviated as in the fourth edition of the World List of Scientific Periodicals and its supplements. In lists of references the publisher and place of publication of books should be given; editions other than the first should be indicated.

Copyright/Offprints. Authors submitting a manuscript do so on the understanding that if it is accepted for publication, copyright in the paper for the United States of America shall be assigned to the Society. In consideration for the assignment of copyright, the Society will supply 50 offprints of each paper, but not of Short Communications or Book Reviews. Further offprints may be ordered at extra cost at the proof stage. The Society will not put any limitation on the personal freedom of the author to use material contained in the paper in other works which may be published in North America or elsewhere. Reprints must be ordered directly from Academic Press Inc. when the author returns the proofs of his article.

Page charges are not levied, but if funds to cover printing costs are available quicker publication, or that of unusually long papers, can be facilitated.

Books dealing with any aspect of lichenology will be reviewed. Publishers wishing to have works reviewed in The Lichenologist should send them to the Senior Editor in the first instance.

This journal is covered by Current Contents and Biological Abstracts.

Notice: While the Senior Editor and Editors endeavour to check the accuracy of statements in contributions in as far as they are able, it should be emphasized that views expressed in papers in The Lichenologist are those of their authors and do not necessarily represent those of the British Lichen Society, Academic Press Inc. (London) Ltd, the Senior Editor, or the Editors.

Referees: The function of referees is to assist members of the British Lichen Society in the identification of lichens. Specimens submitted should be adequate in size and well documented, including details of country, county or vice-county, borough or parish, precise locality and grid reference, altitude, date, habitat and ecology, notes, name of collector and collecting number. Identification should be attempted before sending material to a referee and details of spores and chemical reactions included where appropriate. Members wishing to send large numbers of specimens to a referee should first of all check that he is willing to name their collections for them. Return postage should always be included.

\section{Referees (Beginners)}

F. H. Brightman, B.Sc., F.L.S., South London Botanical Institute, 323 Norwood Road, London SE24 9AQ.

F. S. Dobson, F.L.S., Address under 'Assistant Treasurer'.

O. L. Gilbert, Ph.D., Address under 'Bulletin Editor'.

D. Jackson Hill, D.Phil., Department of Extra-Mural Studies, The University, Bristol BS8 1 HR.

\section{Referees (Advanced)}

B. J. Coppins, Ph.D., Address under 'Vice-President'. (Bacidia and Micarea spp. only.)

A. Fletcher, Ph.D., Center of Marine Biotechnology, Maryland Sea Grant College, University of Maryland, College Park, Maryland 20742, U.S.A. (Marine and maritime lichens.)

Professor D. L. Hawksworth, D.Sc., F.L.S., F.I.Biol., Address under 'President and Senior Editor'. (Lichenicolous fungi.)

P. W. James, B.Sc., F.L.S., Department of Botany, British Museum (Natural History), Cromwell Road, London SW7 5BD. (All groups.)

J. R. Laundon, F.M.A., Department of Botany, British Museum (Natural History), Cromwell Road, London SW7 5BD. (Sterile crustose lichens.)

F. Rose, Ph.D., Rotherhurst, 36 St Mary's Road, Liss, nr Petersfield, Hants GU33 7AH. (Corticolous lichens.)

G. Salisbury, 38 Lostwithiel Street, Fowey, Cornwall. (Thelocarpaceae.)

J. W. Sheard, Ph.D., Address under 'Regional Treasurer'. (Buellia, Rhizocarpon, Rinodina.)

L. Tibell, Ph.D., Institute of Systemic Botany, University of Uppsala, P.O. Box 541, S-751 21 Uppsala 1, Sweden. (Caliciales s. lat.) 
KantVILAS, G. \& JAMES, P. W.-The macrolichens of Tasmanian rainforest: Key and notes

Coppins, B. J. \& Purvis, O. W.-A review of Psilolechia

FARKAS, Edit-Foliicolous lichens of the Usambara Mountains, Tanzania I

Christensen, S. N.-Morphological and chemical variation in the Cladonia macilenta/bacillaris aggregate in Denmark

FAHSELT, Dianne-Electrophoretic analysis of esterase and alkaline phosphatase enzyme forms in single spore cultures of Cladonia cristatella

CHester, T. W. \& HrTch, C. J. B.-Field meeting in Northamptonshire

\section{SHORT COMMUNICATION}

COPPINS, B. J., JaMES, P. W. \& HAWksworth, D. L.-The generic names Placynthiella Elenkin, Saccomorpha Elenkin and Placynthiella Gyelnik

1987 British Lichen Society. The appearance of the code at the bottom of the first page of a paper in this journal indicates the copyright owner's consent that copies of the paper may be made for personal or internal use, or for the personal or internal use of specific clients in the U.S.A. This consent is given on the condition, within the U.S.A., that the copier pay the stated per copy fee through the Copyright Clearance Center, Inc., 27 Congress Street, Salem, MA 01970, for copying beyond that permitted by Sections 107 or 108 of the U.S. Copyright Law. This consent does not extend to other kinds of copying, such as copying for general distribution, for advertising or promotional purposes, for creating new collective works, for resale or for copying or distributing copies outside the U.S.A.

Published four times a year for the British Lichen Society by Academic Press Inc. (London) Ltd, 24-28 Oval Road, London NW1 7DX, England 